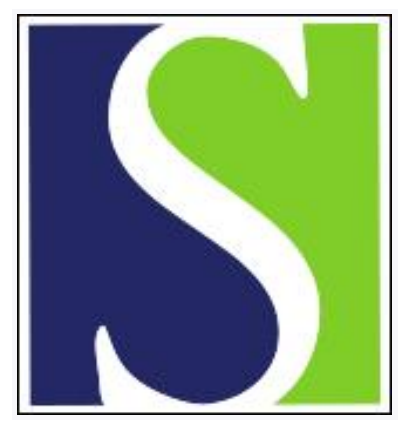

Scand J Work Environ Health 2008;34(4):250-259

https://doi.org/10.5271/sjweh.1269

Published online: 22 Sep 2008, Issue date: Aug 2008

Are occupational factors important determinants of socioeconomic inequalities in musculoskeletal pain?

by Mehlum IS, Kristensen P, Kjuus H, Wergeland E

Affiliation: National Institute of Occupational Health, PO Box 8149 Dep, N-0033 Oslo, Norway. ism@stami.no

Refers to the following texts of the Journal: 2007;33(3):165-191

2005;31(6):409-437 1997;23(5):370-377

The following articles refer to this text: 2008;34(4):235-238;

2009;35(3):222-232; 2009;35(6):429-436; 2014;40(1):1-3;

2014;40(4):380-389

Key terms: arm pain; determinant; job autonomy; low-back pain; musculoskeletal pain; neck pain; occupational class; occupational factor; occupational health; physical job demands; questionnaire; self-assessment; self-report; self-reported symptom; shoulder pain; socioeconomic inequality

This article in PubMed: www.ncbi.nlm.nih.gov/pubmed/18815713 


\title{
Are occupational factors important determinants of socioeconomic inequalities in musculoskeletal pain?
}

\author{
by Ingrid Sivesind Mehlum, MD, ${ }^{1}$ Petter Kristensen, PhD, ${ }^{1}$ Helge Kjuus, PhD, ${ }^{1}$ Ebba Wergeland, PhD ${ }^{2}$
}

\begin{abstract}
Mehlum IS, Kristensen P, Kjuus H, Wergeland E. Are occupational factors important determinants of socioeconomic inequalities in musculoskeletal pain? Scand J Work Environ Health 2008;34(4);250-259.
\end{abstract}

\begin{abstract}
Objectives The aim of this study was to quantify socioeconomic inequalities in low-back pain, neck-shoulder pain, and arm pain in the general working population in Oslo and to examine the impact of job characteristics on these inequalities.

Methods All economically active 30-, 40-, and 45-year-old persons who attended the Oslo health study in 2000-2001 and answered questions on physical job demands, job autonomy, and musculoskeletal pain were included ( $\mathrm{N}=7293)$. Occupational class was used as an indicator of socioeconomic status. The lower occupational classes were compared with higher grade professionals, and prevalences, prevalence ratios, prevalence differences, and population attributable fractions were calculated.

Results There were marked, stepwise socioeconomic gradients for musculoskeletal pain, steeper for the men than for the women. The relative differences (prevalence ratios) were larger for low-back pain and arm pain than for neck-shoulder pain. The absolute differences (prevalence differences) were the largest for low-back pain. Physical job demands explained a substantial proportion of the absolute occupational class inequalities in lowback pain, while job autonomy was more important in explaining the inequalities in neck-shoulder pain and arm pain. The estimated population attributable fractions supported the impact of job characteristics at the working population level, especially for low-back pain.

Conclusions In this cross-sectional study, physical job demands and job autonomy explained a substantial proportion of occupational class inequalities in self-reported musculoskeletal pain in the working population in Oslo. This finding indicates that the workplace may be an important arena for preventive efforts to reduce socioeconomic inequalities in musculoskeletal pain.
\end{abstract}

Key terms arm pain; job autonomy; low-back pain; neck pain; occupational class; occupational health; physical job demands; questionnaire; self-reported symptom; shoulder pain.

Socioeconomic inequalities in health are well documented. The impact of work conditions on socioeconomic inequalities has been studied for various health outcomes [eg, mortality (1), coronary heart disease (2), self-rated general health (3-8), and mental health (8)]. A few studies have examined the impact of work conditions on socioeconomic inequalities in musculoskeletal disorders, measured as physician-diagnosed disorders (9), self-reported disorders diagnosed by a physician (10), sickness absence $(11,12)$, or disability pensioning (13). Aittomäki et al (10) showed that the occupational class-gradient in musculoskeletal disorders was largely explained by physical demands at work. Melchior et al (9) found that physical work factors accounted for over $50 \%$ of the differences between manual workers and other workers in physician-diagnosed upper-limb disorders, higher for some diagnoses. Melchior et al (11) also reported that work conditions explained approximately $25 \%$ of the occupational class-gradients in musculoskeletal-related sickness absence. Hagen et al (13) found that the inverse association between education and occupational disability from back pain was partly mediated through work conditions. However, data on the impact of different occupational factors on socioeconomic inequalities in musculoskeletal pain in specific body regions have rarely been reported.

The Oslo health study, in 2000-2001, of which our present study is a part, was initiated to examine the health status and socioeconomic health inequalities among Oslo citizens (14). Previous studies have shown large geographic and socioeconomic inequalities in Oslo $(15,16)$. We have recently reported high prevalences of

1 National Institute of Occupational Health, Oslo, Norway.

2 Norwegian Labour Inspection Authority, Oslo, Norway.

Reprint requests to: Dr I Sivesind Mehlum, National Institute of Occupational Health, PO Box 8149 Dep, N-0033 Oslo, Norway. [E-mail: ism@stami.no] 
work-related health problems in this population (17). There is evidence that certain job characteristics, such as physical job demands and job autonomy, are risk factors for musculoskeletal disorders (18). Lower social classes tend to have higher prevalences of harmful work conditions, which can partly explain socioeconomic inequalities in health $(4,5,9,10)$. These issues need to be explored further.

The aim of our present study was to quantify socioeconomic inequalities in low-back pain, neck-shoulder pain, and arm pain in the general working population in Oslo and to examine the impact of physical job demands and job autonomy on these inequalities. Our hypothesis was that musculoskeletal pain is associated with occupational class and that this association can partly be explained by job characteristics and may vary between body regions.

\section{Study population and methods}

\section{Study population}

The Oslo health study, a cross-sectional population study, was conducted in 2000-2001 in joint collaboration between the Norwegian Institute of Public Health, the University of Oslo, and the municipality of Oslo. Everyone in Oslo County born in 1970, 1960, 1955, 1940-1941, and 1924-1925 were invited by letter to attend a health screening, and the three youngest cohorts were selected for our present study ( $\mathrm{N}=26074)$. Of these people, $10712(41 \%)$ attended a physical examination or filled out at least one questionnaire in the Oslo health study (17). An age-specific supplementary questionnaire, which included questions on musculoskeletal pain, was returned by 8594 persons (33\%). The response frequency was higher among the women than among the men, and it increased with age. Persons with little education, low income, disability benefit, or nonwestern origin were under-represented (17). We have studied the 7293 (28\%) respondents to this questionnaire with data on musculoskeletal pain, occupation, and job characteristics, 4042 women and 3251 men (table 1).

\section{Questionnaires and study outcome}

The main questionnaire was distributed with the letter of invitation. Two supplementary questionnaires were handed out at the health screening with pre-stamped self-addressed envelopes. The questionnaires asked for information on health status, symptoms, diseases, and various aspects of health behavior (14). The questions on musculoskeletal pain were similar to those used by Statistics Norway in regular national surveys (19). The introductory question, "Have you experienced any of the following common health problems in the last month?" was followed by a list of health problems; among them were pain in neck or shoulders, pain in the elbow, forearm or hand, and low-back pain (17).

\section{Determinants}

Occupational class. The indicator of socioeconomic status was based on questions on the participants' longest held occupation in the past 12 months, classified according to the Erikson-Goldthorpe-Portocarero (EGP) schema $(20,21)$. Because $61 \%$ of the women were in category III (routine nonmanual employees), this category was subdivided into IIIa (eg, nurses, teachers) and IIIb (eg, nursing assistants, shop salespersons), as in the full 11-class version of the EGP schema $(21,22)$. Only 27 women $(0.6 \%)$ were in category V (lower-grade technicians and supervisors of manual workers). Category V and VI (skilled manual workers) were therefore collapsed, as in the 7-class version of the schema (21), and called "skilled workers" (eg, building trade workers, home helpers), leaving seven categories in the analyses (table 1).

Job characteristics. Two separate job characteristics were measured, each by one question. Physical job demands were measured by asking "How would you

Table 1. Distribution of the men $(\mathrm{N}=3251)$ and women $(\mathrm{N}=4042)$ according to the background factors and determinant variables.

\begin{tabular}{lcc}
\hline & Men (\%) & Women (\%) \\
\cline { 2 - 3 } Age & & \\
30 years & 39 & 38 \\
40 years & 32 & 31 \\
45 years & 29 & 30 \\
Country of birth & & \\
Norway & 85 & 86 \\
Western countries & 5 & 7 \\
Nonwestern countries & 10 & 7 \\
Occupational class & & \\
I Higher grade professionals & 30 & 18 \\
II Lower grade professionals & 13 & 10 \\
IIIa Routine nonmanual, higher & 20 & 34 \\
IIIb Routine nonmanual, lower & 9 & 27 \\
IV Self-employed workers & 10 & 6 \\
V+VI Skilled workers & 10 & 2 \\
VII Unskilled workers & 8 & 3 \\
Physical job demands & & \\
Walking & 19 & 25 \\
Sedentary work & 65 & 59 \\
Walking and lifting & 14 & 16 \\
Heavy physical work & 2 & 0 \\
Job autonomy & & \\
4 (high) & 20 & 12 \\
3 & 58 & 56 \\
2 (low) & 18 & 28 \\
\hline & & \\
\hline
\end{tabular}


describe your current work?", followed by four mutually exclusive response categories: "mainly sedentary work", "work involving a lot of walking", "work involving a lot of walking and lifting", and "heavy physical work". Job autonomy was assessed with the question, "Can you yourself decide how your work should be organized?", with the following response categories: "no, not at all", "to a small degree", "yes, largely", and "yes, I decide myself", ranging from 1 (low) to 4 (high) autonomy in the analyses.

The general characteristics of the study population are shown in table 1. Gender differences were observed. Men were more frequently professionals, skilled or unskilled workers, had sedentary or heavy physical work, and had high job autonomy, while the women were more often routine nonmanual employees, had a lot of walking in their work, and had lower job autonomy.

The participants with heavy physical work generally had lower job autonomy, while those with sedentary work had higher autonomy (data not shown).

\section{Statistical analyses}

Analyses were performed using Stata/SE 9.2 software (www.stata.com). Associations between occupational class and musculoskeletal pain were estimated both as prevalence ratios and prevalence differences (23) with their corresponding $95 \%$ confidence intervals $(95 \% \mathrm{CI})$, using the BINREG procedure (binomial regression) in Stata. Since musculoskeletal pain was prevalent, we did not use the more conventional odds ratios in the logistic regression $(24,25)$. Physical job demands and job autonomy were added separately and together in four multivariate models for each of the three study outcomes of low-back pain, neck-shoulder pain, and arm pain (pain in elbow, forearm, or hand). We calculated the percentage of change in the prevalence difference by adding each factor to the model. Model 1 included age $(30,40$ or 45 years) and country of birth (Norway, western countries, or nonwestern countries) in addition to occupational class. Model 2 included physical job demands, in addition to model-1 factors. Model 3 included job autonomy, in addition to model-1 factors. Model 4 included all of the determinants.

The highest occupational class (I), work involving a lot of walking, and the highest category of job autonomy (4) were chosen as reference categories. Interaction between physical job demands and job autonomy was checked for, but the analyses were inconclusive due to collinearity.

The population attributable fraction (PAF) can be interpreted as the proportional reduction in the population prevalence in the hypothetical case that the whole population experiences the prevalence of the reference category (26). Population attributable fractions for occupational class were estimated in the AFLOGIT procedure in Stata after the inclusion of the determinants in the regression model as dummy variables (27).

\section{Ethics approval}

The study protocol was approved by the Norwegian Data Inspectorate and recommended by the Regional Committee for Medical Research Ethics.

\section{Results}

\section{Prevalence of musculoskeletal pain}

The distributions of low-back pain, neck-shoulder pain, and arm pain are shown in table 2 (men) and table 3 (women) according to occupational class and job characteristics. The lower occupational classes had higher prevalences of musculoskeletal pain. Among the unskilled workers, $62 \%$ of the women and $66 \%$ of the men reported low-back pain in the past month, while, among the higher grade professionals, the corresponding percentages were $43 \%$ and $35 \%$, respectively. The prevalences were the lowest for arm pain and the highest for neck-shoulder pain. The differences between the three highest occupational classes (I, II and IIIa) were, in general, only minor. The prevalences for the self-employed workers (IV) were close to the overall prevalences of the population. Gender differences were the largest for the higher occupational classes.

The crude prevalences for musculoskeletal pain were the highest for the participants with heavy physical work. For both genders, low-back pain was the least prevalent among the participants with sedentary work, while arm pain was the least prevalent for both genders and neck-shoulder pain for women among the participants with a lot of walking in their work. Low autonomy was associated with musculoskeletal pain for both genders; the lower the autonomy, the higher the prevalence.

\section{Relative and absolute differences in the prevalence of musculoskeletal pain}

The relative socioeconomic gradient (prevalence ratio) was steeper for low-back pain and arm pain than for neck-shoulder pain, and steeper for the men (table 2) than for the women (table 3). For the unskilled workers, compared with the higher grade professionals, the prevalence ratio for low-back pain was 1.7 for the men and 1.3 for the women.

The absolute differences in occupational class (prevalence differences) in model 1 were also larger for the men (table 4) than for the women (table 5), and larger 
Table 2. Prevalences and prevalence ratios for self-reported musculoskeletal pain according to occupational class, physical job demands, and job autonomy among the men. $(95 \% \mathrm{Cl}=95 \%$ confidence interval)

\begin{tabular}{|c|c|c|c|c|c|c|c|c|c|c|}
\hline \multirow[b]{3}{*}{ All men } & \multirow[t]{2}{*}{$\mathrm{N}$} & \multicolumn{3}{|c|}{ Low-back pain } & \multicolumn{3}{|c|}{ Neck-shoulder pain } & \multicolumn{3}{|c|}{ Arm pain } \\
\hline & & $\begin{array}{c}\text { Prevalence a } \\
(\%)\end{array}$ & $\begin{array}{c}\text { Prevalence } \\
\text { ratio }^{\mathrm{b}}\end{array}$ & $95 \% \mathrm{Cl}$ & $\begin{array}{c}\text { Prevalence a } \\
(\%)\end{array}$ & $\begin{array}{c}\text { Prevalence } \\
\text { ratio }^{b}\end{array}$ & $95 \% \mathrm{Cl}$ & $\begin{array}{c}\text { Prevalence a } \\
(\%)\end{array}$ & $\begin{array}{c}\text { Prevalence } \\
\text { ratio }^{b}\end{array}$ & $95 \% \mathrm{Cl}$ \\
\hline & 3251 & 43 & . & . & 43 & . & . & 23 & . & . \\
\hline \multicolumn{11}{|l|}{ Occupational class } \\
\hline $\begin{array}{l}\text { I Higher grade professionals } \\
\text { II Lower grade professionals } \\
\text { IIIa Routine nonmanual, higher } \\
\text { IIIb Routine nonmanual, lower } \\
\text { IV Self-employed workers } \\
\text { V+VI Skilled workers } \\
\text { VII Unskilled workers }\end{array}$ & $\begin{array}{l}975 \\
435 \\
634 \\
301 \\
329 \\
320 \\
257\end{array}$ & $\begin{array}{l}35 \\
33 \\
39 \\
52 \\
46 \\
58 \\
66\end{array}$ & $\begin{array}{l}1 \\
1.0 \\
1.1 \\
1.5 \\
1.2 \\
1.6 \\
1.7\end{array}$ & $\begin{array}{c}\cdots \\
0.8-1.1 \\
1.0-1.3 \\
1.3-1.7 \\
1.1-1.4 \\
1.4-1.8 \\
1.5-1.9\end{array}$ & $\begin{array}{l}40 \\
42 \\
37 \\
50 \\
44 \\
47 \\
61\end{array}$ & $\begin{array}{l}1 \\
1.1 \\
0.9 \\
1.2 \\
1.0 \\
1.1 \\
1.3\end{array}$ & $\begin{array}{l}* . \\
0.9-1.2 \\
0.8-1.1 \\
1.0-1.3 \\
0.9-1.2 \\
1.0-1.3 \\
1.2-1.5\end{array}$ & $\begin{array}{l}20 \\
21 \\
17 \\
26 \\
26 \\
32 \\
39\end{array}$ & $\begin{array}{l}1 \\
1.0 \\
0.9 \\
1.2 \\
1.2 \\
1.5 \\
1.7\end{array}$ & $\begin{array}{l}\ddot{.} \\
0.8-1.3 \\
0.7-1.1 \\
0.9-1.5 \\
1.0-1.5 \\
1.2-1.9 \\
1.4-2.0\end{array}$ \\
\hline \multicolumn{11}{|l|}{ Physical job demands } \\
\hline $\begin{array}{l}\text { Walking } \\
\text { Sedentary work } \\
\text { Walking and lifting } \\
\text { Heavy physical work }\end{array}$ & $\begin{array}{r}617 \\
2099 \\
457 \\
78\end{array}$ & $\begin{array}{l}49 \\
37 \\
58 \\
69\end{array}$ & $\begin{array}{l}1 \\
0.8 \\
1.2 \\
1.4\end{array}$ & $\begin{array}{c}. . \\
0.7-0.9 \\
1.1-1.3 \\
1.2-1.6\end{array}$ & $\begin{array}{l}43 \\
41 \\
49 \\
67\end{array}$ & $\begin{array}{l}1 \\
1.0 \\
1.1 \\
1.4\end{array}$ & $\begin{array}{c}. . \\
0.9-1.1 \\
1.0-1.3 \\
1.2-1.7\end{array}$ & $\begin{array}{l}20 \\
21 \\
32 \\
23\end{array}$ & $\begin{array}{l}1 \\
1.2 \\
1.5 \\
2.5\end{array}$ & $\begin{array}{c}. . \\
1.0-1.4 \\
1.3-1.9 \\
2.0-3.2\end{array}$ \\
\hline \multicolumn{11}{|l|}{ Job autonomy } \\
\hline $\begin{array}{l}4 \text { (high) } \\
3 \\
2 \\
1 \text { (low) }\end{array}$ & $\begin{array}{r}659 \\
1893 \\
587 \\
112\end{array}$ & $\begin{array}{l}37 \\
40 \\
53 \\
67\end{array}$ & $\begin{array}{l}1 \\
1.1 \\
1.4 \\
1.5\end{array}$ & $\begin{array}{c}. . \\
1.0-1.2 \\
1.2-1.6 \\
1.3-1.8\end{array}$ & $\begin{array}{l}37 \\
41 \\
52 \\
70\end{array}$ & $\begin{array}{l}1 \\
1.1 \\
1.4 \\
1.6\end{array}$ & $\begin{array}{c}. . \\
1.0-1.3 \\
1.2-1.5 \\
1.3-1.8\end{array}$ & $\begin{array}{l}20 \\
22 \\
27 \\
45\end{array}$ & $\begin{array}{l}1 \\
1.1 \\
1.3 \\
1.7\end{array}$ & $\begin{array}{c}. \ddot{ } \\
0.9-1.3 \\
1.1-1.6 \\
1.3-2.3\end{array}$ \\
\hline
\end{tabular}

a Unadjusted, expressed as percentages, excluding missing answers.

${ }^{\mathrm{b}}$ Adjusted for age and country of birth.

Table 3. Prevalences and prevalence ratios for self-reported musculoskeletal pain according to occupational class, physical job demands, and job autonomy among the women. (95\% $\mathrm{Cl}=95 \%$ confidence interval)

\begin{tabular}{|c|c|c|c|c|c|c|c|c|c|c|}
\hline & \multirow[t]{2}{*}{ N } & \multicolumn{3}{|c|}{ Low-back pain } & \multicolumn{3}{|c|}{ Neck-shoulder pain } & \multicolumn{3}{|c|}{ Arm pain } \\
\hline & & $\begin{array}{c}\text { Prevalence }{ }^{\mathrm{a}} \\
(\%)\end{array}$ & $\begin{array}{c}\text { Prevalence } \\
\text { ratio }^{b}\end{array}$ & e $95 \% \mathrm{Cl}$ & $\begin{array}{c}\text { Prevalence }^{\mathrm{a}} \\
(\%)\end{array}$ & $\begin{array}{l}\text { Prevalence } \\
\text { ratio }^{b}\end{array}$ & $95 \% \mathrm{Cl}$ & $\begin{array}{c}\text { Prevalence }{ }^{\mathrm{a}} \\
(\%)\end{array}$ & $\begin{array}{c}\text { Prevalence } \\
\text { ratio }^{\mathrm{b}}\end{array}$ & $95 \% \mathrm{Cl}$ \\
\hline All women & 4042 & 48 & . & . & 60 & . & . & 30 & . & . \\
\hline \multicolumn{11}{|l|}{ Occupational class } \\
\hline $\begin{array}{l}\text { I Higher grade professionals } \\
\text { II Lower grade professionals } \\
\text { IIla Routine nonmanual, higher } \\
\text { IIIb Routine nonmanual, lower } \\
\text { IV Self-employed workers } \\
\text { V+VI Skilled workers } \\
\text { VII Unskilled workers }\end{array}$ & $\begin{array}{r}709 \\
417 \\
1360 \\
1111 \\
223 \\
89 \\
133\end{array}$ & $\begin{array}{l}43 \\
42 \\
44 \\
54 \\
50 \\
60 \\
62\end{array}$ & $\begin{array}{l}1 \\
1.0 \\
1.0 \\
1.3 \\
1.2 \\
1.4 \\
1.3\end{array}$ & $\begin{array}{l}\ddot{ } \\
0.9-1.1 \\
0.9-1.2 \\
1.1-1.4 \\
1.0-1.4 \\
1.1-1.7 \\
1.1-1.6\end{array}$ & $\begin{array}{l}59 \\
55 \\
57 \\
65 \\
59 \\
72 \\
70\end{array}$ & $\begin{array}{l}1 \\
0.9 \\
1.0 \\
1.1 \\
1.0 \\
1.2 \\
1.1\end{array}$ & $\begin{array}{l}\ddot{.} \\
0.8-1.0 \\
0.9-1.1 \\
1.0-1.2 \\
0.9-1.1 \\
1.0-1.4 \\
1.0-1.3\end{array}$ & $\begin{array}{l}28 \\
30 \\
26 \\
33 \\
29 \\
37 \\
46\end{array}$ & $\begin{array}{l}1 \\
1.1 \\
0.9 \\
1.1 \\
1.0 \\
1.3 \\
1.4\end{array}$ & $\begin{array}{l}. . \\
0.9-1.3 \\
0.8-1.1 \\
1.0-1.3 \\
0.8-1.3 \\
0.9-1.7 \\
1.1-1.7\end{array}$ \\
\hline \multicolumn{11}{|l|}{ Physical job demands } \\
\hline $\begin{array}{l}\text { Walking } \\
\text { Sedentary work } \\
\text { Walking and lifting } \\
\text { Heavy physical work }\end{array}$ & $\begin{array}{r}996 \\
2393 \\
638 \\
15\end{array}$ & $\begin{array}{l}47 \\
44 \\
62 \\
67\end{array}$ & $\begin{array}{l}1 \\
0.9 \\
1.3 \\
1.2\end{array}$ & $\begin{array}{c}. . \\
0.9-1.0 \\
1.2-1.4 \\
0.9-1.8\end{array}$ & $\begin{array}{l}57 \\
61 \\
62 \\
73\end{array}$ & $\begin{array}{l}1 \\
1.1 \\
1.1 \\
1.4\end{array}$ & $\begin{array}{c}. . \\
1.0-1.2 \\
1.0-1.2 \\
1.2-1.5\end{array}$ & $\begin{array}{l}23 \\
31 \\
35 \\
50\end{array}$ & $\begin{array}{l}1 \\
1.4 \\
1.5 \\
1.6\end{array}$ & $\begin{array}{c}. . \\
1.2-1.6 \\
1.3-1.7 \\
1.0-2.6\end{array}$ \\
\hline \multicolumn{11}{|l|}{ Job autonomy } \\
\hline $\begin{array}{l}4 \text { (high) } \\
3 \\
2 \\
1 \text { (low) }\end{array}$ & $\begin{array}{r}505 \\
2261 \\
1113 \\
163\end{array}$ & $\begin{array}{l}43 \\
46 \\
51 \\
62\end{array}$ & $\begin{array}{l}1 \\
1.1 \\
1.2 \\
1.3\end{array}$ & $\begin{array}{c}. . \\
1.0-1.2 \\
1.1-1.3 \\
1.1-1.5\end{array}$ & $\begin{array}{l}55 \\
59 \\
64 \\
70\end{array}$ & $\begin{array}{l}1 \\
1.1 \\
1.2 \\
1.2\end{array}$ & $\begin{array}{c}. . \\
1.0-1.2 \\
1.1-1.3 \\
1.1-1.4\end{array}$ & $\begin{array}{l}29 \\
28 \\
33 \\
43\end{array}$ & $\begin{array}{l}1 \\
1.0 \\
1.1 \\
1.3\end{array}$ & $\begin{array}{c}. . \\
0.8-1.1 \\
1.0-1.3 \\
1.0-1.6\end{array}$ \\
\hline
\end{tabular}

a Unadjusted, expressed as percentages, excluding missing answers.

${ }^{\mathrm{b}}$ Adjusted for age and country of birth.

for low-back pain than for neck-shoulder pain and arm pain. The prevalence of low-back pain for the male unskilled workers was 25 percentage points higher than for the higher grade professionals, compared with a difference of 15 percentage points for the women. For neck-shoulder pain and arm pain, the corresponding 
Table 4. Prevalences and prevalence differences (PD) of self-reported musculoskeletal pain among the men $(\mathrm{N}=3251)$. $(95 \% \mathrm{Cl}=95 \%$ confdence interval)

\begin{tabular}{|c|c|c|c|c|c|c|c|c|c|}
\hline \multirow[t]{2}{*}{ Type of pain } & \multirow[t]{2}{*}{ Prevalence (\%) } & \multicolumn{2}{|c|}{ Model $1^{a}$} & \multicolumn{2}{|c|}{ Model $2^{b}$} & \multicolumn{2}{|c|}{ Model $3^{c}$} & \multicolumn{2}{|c|}{ Model $4^{\mathrm{d}}$} \\
\hline & & PD & $95 \% \mathrm{Cl}$ & PD & $95 \% \mathrm{Cl}$ & PD & $95 \% \mathrm{Cl}$ & $\mathrm{PD}$ & $95 \% \mathrm{Cl}$ \\
\hline \multicolumn{10}{|l|}{ Low-back pain } \\
\hline I Higher grade professionals & 35 & - & .. & - & .. & - &.. & - & .. \\
\hline II Lower grade professionals & 33 & -1 & $-7-4$ & -2 & $-7-4$ & -1 & $-7-4$ & -2 & $-7-4$ \\
\hline Illa Routine nonmanual, higher & 39 & 5 & $0-10$ & 4 & $-1-9$ & 4 & $-1-8$ & 3 & $-2-8$ \\
\hline Illb Routine nonmanual, lower & 52 & 15 & $9-22$ & 12 & $6-19$ & 14 & $7-20$ & 11 & $4-17$ \\
\hline IV Self-employed workers & 46 & 8 & $2-14$ & 5 & $-1-11$ & 10 & $4-16$ & 7 & $1-13$ \\
\hline V+VI Skilled workers & 58 & 21 & $15-27$ & 13 & $6-20$ & 19 & $13-25$ & 12 & $5-19$ \\
\hline VII Unskilled workers & 66 & 25 & $19-32$ & 20 & $13-27$ & 21 & $14-28$ & 17 & $9-24$ \\
\hline \multicolumn{10}{|l|}{ Neck-shoulder pain } \\
\hline I Higher grade professionals & 40 & - & .. & - & .. & - &.. & - & .. \\
\hline II Lower grade professionals & 42 & 2 & $-4-7$ & 2 & $-4-7$ & 2 & $-3-8$ & 2 & $-4-7$ \\
\hline Illa Routine nonmanual, higher & 37 & -2 & $-7-2$ & -2 & $-7-3$ & -4 & $-9-1$ & -4 & $-8-1$ \\
\hline Illb Routine nonmanual, lower & 50 & 7 & $0-13$ & 7 & $0-13$ & 5 & $-2-11$ & 5 & $-2-12$ \\
\hline IV Self-employed workers & 44 & 1 & $-5-8$ & 1 & $-6-7$ & 4 & $-3-10$ & 3 & $-3-10$ \\
\hline V+VI Skilled workers & 47 & 4 & $-2-11$ & 2 & $-5-9$ & 2 & $-4-8$ & 1 & $-6-8$ \\
\hline VII Unskilled workers & 61 & 15 & 8-22 & 14 & $7-21$ & 10 & $3-17$ & 10 & $3-17$ \\
\hline \multicolumn{10}{|l|}{ Arm pain } \\
\hline I Higher grade professionals & 20 & - & .. & - & .. & - &.. & - & .. \\
\hline II Lower grade professionals & 21 & 1 & $-4-5$ & - & $-4-5$ & 1 & $-4-6$ & - & $-4-5$ \\
\hline Illa Routine nonmanual, higher & 17 & -2 & $-6-2$ & -1 & $-5-3$ & -2 & $-6-2$ & -1 & $-5-3$ \\
\hline IIlb Routine nonmanual, lower & 26 & 3 & $-2-9$ & 4 & $-2-9$ & 3 & $-3-8$ & 3 & $-2-9$ \\
\hline IV Self-employed workers & 26 & 4 & $-2-9$ & 3 & $-3-8$ & 5 & $-1-10$ & 4 & $-2-9$ \\
\hline V+VI Skilled workers & 32 & 10 & $5-16$ & 8 & $2-14$ & 9 & $4-15$ & 7 & $1-13$ \\
\hline VII Unskilled workers & 39 & 14 & $7-21$ & 13 & $6-20$ & 12 & $5-19$ & 11 & $4-18$ \\
\hline
\end{tabular}

${ }^{\text {a }}$ Adjusted for age and country of birth.

${ }^{\mathrm{b}}$ Adjusted for variables in model 1 and physical job demands.

${ }^{\mathrm{c}}$ Adjusted for variables in model 1 and job autonomy.

${ }^{a}$ Adjusted for variables in model 1, physical job demands, and job autonomy.

Table 5. Prevalences and prevalence differences (PD) of self-reported musculoskeletal pain among the women ( $\mathrm{N}=4042)$. $(95 \% \mathrm{Cl}=95 \%$ confidence interval)

\begin{tabular}{|c|c|c|c|c|c|c|c|c|c|}
\hline \multirow[t]{2}{*}{ Type of pain } & \multirow[t]{2}{*}{ Prevalence (\%) } & \multicolumn{2}{|c|}{ Model $1^{\mathrm{a}}$} & \multicolumn{2}{|c|}{ Model $2^{b}$} & \multicolumn{2}{|c|}{ Model $3^{c}$} & \multicolumn{2}{|c|}{ Model $4^{\mathrm{d}}$} \\
\hline & & PD & $95 \% \mathrm{Cl}$ & PD & $95 \% \mathrm{Cl}$ & PD & $95 \% \mathrm{Cl}$ & $\mathrm{PD}$ & $95 \% \mathrm{Cl}$ \\
\hline \multicolumn{10}{|l|}{ Low back pain } \\
\hline I Higher-grade professionals & 43 & - & .. & - & .. & - & .. & - & .. \\
\hline II Lower-grade professionals & 42 & -1 & $-7-5$ & -1 & $-7-5$ & -1 & $-7-5$ & -1 & $-7-5$ \\
\hline Illa Routine nonmanual, higher & 44 & 2 & $-3-6$ & 0 & $-5-4$ & 1 & $-4-5$ & -1 & $-5-4$ \\
\hline Illb Routine nonmanual, lower & 54 & 11 & $6-16$ & 8 & $3-13$ & 9 & $5-14$ & 7 & $2-12$ \\
\hline IV Self-employed workers & 50 & 7 & $-1-14$ & 5 & $-3-12$ & 8 & $0-16$ & 6 & $-2-13$ \\
\hline V+VI Skilled workers & 60 & 16 & $5-27$ & 11 & $0-22$ & 15 & $4-25$ & 10 & $-1-21$ \\
\hline VII Unskilled workers & 62 & 15 & $5-24$ & 7 & $-2-17$ & 12 & $3--21$ & 6 & $-4-15$ \\
\hline \multicolumn{10}{|l|}{ Neck-shoulder pain } \\
\hline I Higher-grade professionals & 59 & - & .. & - & .. & - & .. & - & .. \\
\hline II Lower-grade professionals & 55 & -4 & $-10-2$ & -4 & $-10-2$ & -4 & $-10-2$ & -4 & $-10-2$ \\
\hline Illa Routine nonmanual, higher & 57 & -1 & $-6-3$ & 0 & $-5-4$ & -2 & $-7-2$ & -1 & $-6-3$ \\
\hline IIlb Routine nonmanual, lower & 65 & 5 & $0-10$ & 6 & $1-11$ & 3 & $-2-8$ & 4 & $-1-9$ \\
\hline IV Self-employed workers & 59 & -1 & $-9-6$ & 0 & $-8-7$ & 0 & $-7-8$ & 2 & $-6-10$ \\
\hline V+VI Skilled workers & 72 & 12 & $2-22$ & 13 & $3-23$ & 9 & $-1-19$ & 10 & $0-20$ \\
\hline VII Unskilled workers & 70 & 8 & $-1-16$ & 9 & $0-18$ & 6 & $-3-15$ & 7 & $-2-16$ \\
\hline \multicolumn{10}{|l|}{ Arm pain } \\
\hline I Higher-grade professionals & 28 & - & .. & - & .. & - & .. & - & .. \\
\hline II Lower-grade professionals & 30 & 1 & $-5-6$ & 1 & $-4-7$ & 1 & $-5-6$ & 1 & $-4-6$ \\
\hline Illa Routine nonmanual, higher & 26 & -2 & $-6-2$ & -1 & $-5-3$ & -3 & $-7-1$ & -2 & $-6-2$ \\
\hline Illb Routine nonmanual, lower & 33 & 3 & $-2-7$ & 3 & $-1-8$ & 1 & $-3-6$ & 2 & $-3-6$ \\
\hline IV Self-employed workers & 29 & -1 & $-8-6$ & 1 & $-6-7$ & -1 & $-8-6$ & 1 & $-6-8$ \\
\hline V+VI Skilled workers & 37 & 6 & $-4-17$ & 7 & $-4-18$ & 5 & $-6-15$ & 6 & $-5-16$ \\
\hline VII Unskilled workers & 46 & 11 & $2-21$ & 12 & $2-22$ & 9 & $0-19$ & 10 & $0-20$ \\
\hline
\end{tabular}

adjusted for age and country of birth.

${ }^{b}$ Adjusted for variables in model 1 and physical job demands.

${ }^{c}$ Adjusted for variables in model 1 and job autonomy.

${ }^{d}$ Adjusted for variables in model 1, physical job demands, and job autonomy. 
differences were approximately 15 percentage points for the men and 10 percentage points for the women.

\section{Impact of job characteristics}

Adjustment for the two selected job characteristics generally reduced the prevalence differences in musculoskeletal pain between the occupational classes.

Low-back pain. For the male unskilled workers, compared with the higher grade professionals, the prevalence difference for low-back pain was reduced from 25 percentage points in model 1 , to 17 percentage points in model 4 (34\% reduction), and for the male skilled workers the corresponding decrease was from 21 to 12 percentage points (44\%) (table 4). For the women, the corresponding reductions were from 15 to 6 percentage points $(59 \%)$ for the unskilled workers and from 16 to 10 percentage points $(36 \%)$ for the skilled workers (table 5). Most of the reduction occurred when physical job demands (model 2) were entered, resulting in a $22 \%$ and $38 \%$ reduction, respectively, in the two occupational classes for the men and $49 \%$ and $32 \%$, respectively, for the women. Entering job autonomy separately (model 3 ) gave smaller reductions in the prevalence difference for low-back pain, approximately $10-15 \%$ for both genders.

Neck-shoulder pain and arm pain. When job characteristics were adjusted for, the prevalence difference for neck-shoulder pain among the male unskilled workers, compared with the higher grade professionals, was reduced from 15 percentage points in model 1 to 10 percentage points in model 4 (32\% reduction) (table 4 ). For arm pain, the corresponding change was from 14 to 11 percentage points (20\%). For the women the differences were smaller (table 5). Adjustment for physical job demands separately (model 2) generally increased the prevalence difference somewhat for neck-shoulder pain and arm pain among the women and resulted in only small changes among the men. However, entering job autonomy separately (model 3 ) gave somewhat larger reductions in the prevalence difference, $34 \%$ for neck-shoulder pain and $15 \%$ for arm pain among the male unskilled workers and 25\% and 19\%, respectively, among the female unskilled workers.

\section{Population attributable fraction}

Estimates of the population attributable fraction (PAF) are presented in table 6 , ranging from $2 \%$ to $17 \%$ in model 1. Occupational class had a larger impact on the men than on the women for all three body regions, and the largest impact was on low-back pain (PAF estimates of $17 \%$ for the men and $10 \%$ for the women in model 1 ).
Adjustment for physical job demands and job autonomy (model 4) reduced the PAF estimates for occupational class with respect to low-back pain, when compared with the results of model 1, both for the men (30\% reduction) and for the women (50\% reduction). The corresponding PAF estimate for neck-shoulder pain was reduced by $40 \%$ among the men. Adjustment for physical job demands separately (model 2) reduced the PAF estimates for occupational class in respect to all three body regions among the men, but only for low-back pain among the women (data not shown). Adjustment for job autonomy separately (model 3 ) reduced the PAF estimates relatively more for the women than for the men, especially for neck-shoulder pain and arm pain (data not shown).

\section{Discussion}

In this study of 7293 economically active Oslo citizens, aged 30,40 , or 45 years, there were marked, stepwise socioeconomic gradients for musculoskeletal pain, steeper for the men than for the women. The relative occupational class differences were larger for low-back pain and arm pain than for neck-shoulder pain, and the absolute differences were the largest for low-back pain. Physical job demands explained a substantial proportion of the absolute inequalities between the occupational classes for low-back pain, while job autonomy was more important in explaining the inequalities in neck-shoulder pain and arm pain. The PAF estimates supported the impact of the selected job characteristics at the level of the working population, especially for low-back pain.

\section{Methodological considerations}

The Oslo health study is a large population-based study, designed to examine socioeconomic inequalities in

Table 6. Population attributable fractions (PAF) for musculoskeletal pain according to occupational class and the impact of job characteristics. ( $95 \% \mathrm{Cl}=95 \%$ confidence interval)

\begin{tabular}{|c|c|c|c|c|c|c|c|c|}
\hline \multirow[t]{3}{*}{ Type of pain } & \multicolumn{4}{|c|}{ Men $(N=3251)$} & \multicolumn{4}{|c|}{ Women $(\mathrm{N}=4042)$} \\
\hline & \multicolumn{2}{|c|}{ Model $1^{\mathrm{a}}$} & \multicolumn{2}{|c|}{ Model $4^{b}$} & \multicolumn{2}{|c|}{ Model $1^{\mathrm{a}}$} & \multicolumn{2}{|c|}{ Model $4^{b}$} \\
\hline & $\begin{array}{l}\text { PAF } \\
(\%)\end{array}$ & $95 \% \mathrm{Cl}$ & $\begin{array}{l}\text { PAF } \\
(\%)\end{array}$ & $95 \% \mathrm{Cl}$ & $\begin{array}{l}\text { PAF } \\
(\%)\end{array}$ & $95 \% \mathrm{Cl}$ & $\begin{array}{l}\text { PAF } \\
(\%)\end{array}$ & $95 \% \mathrm{Cl}$ \\
\hline Low-back pain & 17 & $12-22$ & 12 & $7-17$ & 10 & $5-15$ & 5 & $0-11$ \\
\hline $\begin{array}{l}\text { Neck-shoulder } \\
\text { pain }\end{array}$ & 5 & $0-10$ & 3 & $-2-8$ & 2 & $-2-5$ & 2 & $-2-5$ \\
\hline Arm pain & 12 & $3-20$ & 11 & $1-19$ & 3 & $-6-11$ & 3 & $-6-12$ \\
\hline
\end{tabular}

a Adjusted for age and country of birth.

${ }^{b}$ Adjusted for the variables in model 1, physical job demands, and job autonomy. 
health. All of the participants in certain age cohorts were invited, and they represented the full variety of occupations in Oslo.

The low attendance in the study could obviously have led to selection bias. This possibility has been thoroughly examined in the Oslo health study $(17,28)$. Søgaard et al (28) evaluated the effect of self-selection in the main survey and found that unhealthy persons seemed to attend to a less degree than healthy persons but concluded that social inequality in health by different sociodemographic variables nevertheless seemed unbiased on a ratio scale (28). Mehlum et al (17) found that the response to the supplementary questionnaire with data on musculoskeletal pain was lower in the subgroups with poorer health. This finding may imply conservative estimates of the pain prevalences and thus conservative estimates of the prevalence difference and the population attributable fraction. The consistency between the results of the Oslo health study and the survey of living conditions in 2000 from Statistics Norway, based on a representative population sample, did not, however, indicate a serious selection problem (17). Increasing nonparticipation has been a problem in many epidemiologic studies, especially in recent years, but most empirical work suggests that declines in participation rates are not likely to substantially influence exposure-disease associations (29). However, nonparticipation may influence descriptive results to a higher degree, often leading to underestimated prevalences of ill-health.

Among the 8594 respondents, data on occupation were missing for $11 \%$ of the men and $13 \%$ of the women, many of whom were not working. In Norway, $83 \%$ of the women and $90 \%$ of the men aged 30-44 years were employed in 2000-2001, and employment was somewhat higher in Oslo than in Norway as a whole, especially among the women (30). The exclusion of the economically inactive can lead to an underestimation of the socioeconomic differences in the total population ( 7 , 31). However, the prevalences of musculoskeletal pain were almost identical in the whole population as among the participants of either gender with data on occupation, even though the participants without information on occupation generally had somewhat higher prevalences (data not shown).

The cross-sectional design of our study does not allow causal inference between our independent and outcome variables. A stronger tendency to report heavy work or low job autonomy among the participants with pain (32) cannot be ruled out. A lack of randomization in observational studies may lead to selection processes, which are particularly difficult to control in cross-sectional studies. The health-related job change of the participants with health problems, from heavier work in lower occupational classes to lighter work in higher occupational classes, would lead to conservative estimates
(33), as would socioeconomic differences in the healthy worker effect, with a higher tendency towards the selection of unhealthy persons completely out of work in lower occupational classes (34).

The self-report of exposure and outcome, as in our present study, could lead to misclassification. However, in a review by Stock et al (35), questions on sitting and standing posture, walking, manual handling, and the general level of physical effort were found to perform well with respect to reproducibility and validity (35). We assume that the respondents were able to discriminate well between the crude categories employed for physical job demands and job autonomy in our questionnaire. Pain is a subjective phenomenon and cannot readily be validated. However, Björkstén et al (36) found both sensitivity and specificity to be high when questionnaire answers on musculoskeletal pain were compared with a clinical assessment.

Self-reported data on both the determinants and outcome variables could also inflate the results due to common method bias $(37,38)$ (eg, in relation to personality traits such as negative affectivity). The questions on job characteristics and musculoskeletal pain were, however, separated in different questionnaires, among questions on other topics. In addition, the job characteristics and musculoskeletal pain had different types of response categories. These factors may reduce common method bias due to self-report tendencies (38). In a study of musculoskeletal disorders among the general working population, Toomingas et al (39) found no support for bias from rating behavior when the participants rated both exposure and outcome (39). However, we cannot exclude the possibility that common method bias may have inflated our results.

\section{Socioeconomic differences}

Trends in socioeconomic inequalities in self-assessed health have been more stable in Norway than in some European countries, where inequalities have been widening $(40,41)$. Still large socioeconomic inequalities in morbidity (41) and mortality (42) remain. Aittomäki et al (10) found smaller occupational class differences in musculoskeletal disorders than in self-rated health and suggested that a fairly high prevalence of musculoskeletal disorders may explain the less steep gradient. Our present study showed a higher prevalence and a less steep gradient for neck-shoulder pain than for low-back pain among the women, while, among the men, there was both a fairly high prevalence and a relatively steep gradient for low-back pain. Musculoskeletal pain is very common in the population and may be considered a normal phenomenon (43). Nevertheless, there are socioeconomic differences. 
The gradient was lower than what has been found for musculoskeletal disorders as a cause of sickness absence $(11,12,44)$ or disability pension (13). Higher severity (45) and a less favorable course of pain episodes (46) in lower socioeconomic classes, in addition to occupation-specific consequences of disease (34), could explain the steeper gradients of sickness absence and disability pensioning. Our outcome measures were crude, with no differentiation between degrees of pain (severity, frequency, duration, etc). We would assume that the inequalities in severe musculoskeletal pain would be larger.

Relative and absolute measures of association may offer different inferences $(23,47,48)$. We found large relative (prevalence ratio) and absolute (prevalence difference) differences for low-back pain and small differences for neck-shoulder pain. For arm pain, the prevalence ratio was large, while the prevalence difference was small. Absolute measures better express the importance of inequalities in terms of the burden of ill-health and financial costs to society $(22,47)$, and they may better serve as a basis for preventive strategies (48).

\section{Impact of job characteristics}

The impact of work conditions on socioeconomic inequalities in musculoskeletal pain has been shown in previous studies (9-13). In our present study, work had a relatively large impact on socioeconomic differences in musculoskeletal pain, even though job characteristics were measured by only two variables. Physical job demands were classified in rather crude categories, but the variable was still able to discriminate the risk of musculoskeletal pain. The inclusion of more job characteristics (eg, more-specific ergonomic risk factors and additional psychosocial factors) could possibly explain a larger proportion of socioeconomic inequalities in musculoskeletal pain (9).

The proportion explained by each of the job characteristics differed between the body regions. Physical job demands explained a substantial proportion of occupational class inequalities in low-back pain, while job autonomy explained a larger proportion of inequalities in neck-shoulder pain. Lifting and heavy physical work are risk factors for low-back pain, and forceful arm-hand movements may cause pain in neck-shoulders and arms (18). Specific physical exposures relevant to arm pain were not captured by our question, and this lack may explain the smaller impact of physical job demands on arm pain. High psychosocial job demands and low job control are often related to neck (49) and upper-limb (50) symptoms, but low job decision latitude (combination of job content and job control) is also a risk factor for low-back pain (51).

\section{Population attributable fractions}

In the Oslo working population, women, aged 30,40 or 45 years, would have had a prevalence of low-back pain that was $10 \%$ lower than what was actually observed if the age groups had all had the same prevalence of lowback pain as the women in the highest occupational class. The corresponding potential reductions among the men were $17 \%$ for low-back pain and $12 \%$ for arm pain. When judged from the change in the population attributable fraction between model 1 and model 4, a substantial part of the occupational class differences in musculoskeletal low-back pain in the working population is explained by the examined job characteristics. Even if the reductions represent hypothetical cases, they give an impression of the potential for prevention at the working population level.

\section{Gender differences}

We found that the socioeconomic gradients for musculoskeletal pain were steeper among the men than among the women. This finding is in accordance with the results of some earlier studies $(3,12,52,53)$, but not with others $(6,10)$. Socioeconomic classification systems based on occupation were originally established for male populations and may be better at classifying men than women (54-56). The same occupational class may have different meanings for men and for women and thus be differently associated with health (57). In our study, gender differences were larger in the higher than in the lower occupational classes. Vahtera et al (12) also found that women, in contrast to men, may not benefit consistently from high socioeconomic status (12). In our present study, the women in higher occupational classes had lower job autonomy than their male counterparts (data not shown). This situation may have contributed to the smaller gradient for the women. Another explanation could be the double burden of paid and unpaid work (58), which may differ between occupational classes. Among the unskilled female workers, $36 \%$ worked part-time, compared with $11 \%$ of the higher grade professionals, but the proportion living with children under the age of 18 years was similar (data not shown).

\section{Socioeconomic indicator}

Galobardes et al (59) recommend that, for socially patterned exposures that have etiological effects specific to particular stages of the life course, socioeconomic indicators should be related to these stages (59). Occupation thus seemed a logical choice as an indicator of socioeconomic status in our study. Socioeconomic classification systems based on occupation may capture specific job-related factors (56), as was apparent in this study. 
The EGP class schema does not have an implicit hierarchical rank (20), and therefore it does not necessarily capture a gradient in health across its groups (60). The self-employed group resembles the white-collar classes in terms of economic factors and social networks, while they are more similar to the working classes when physical work conditions and health behavior are studied (61). Our present study showed a pronounced gradient in musculoskeletal pain; however, the heterogeneity of the self-employed group was also apparent.

In conclusion, in this large population-based study, marked, stepwise socioeconomic gradients in self-reported musculoskeletal pain were observed in the working population, steeper for the men than for the women. Physical job demands and job autonomy explained a substantial proportion of the occupational class inequalities. As the study was cross-sectional, based on self-reported data on both determinants and outcome, the results should be interpreted with caution. However, the results indicate that interventions to reduce heavy physical work and lifting and increase job autonomy may reduce socioeconomic inequalities in the occurrence of musculoskeletal pain.

\section{Acknowledgments}

This study was supported financially by The Confederation of Norwegian Business and Industry's Working Environment Fund, Oslo, Norway, and The Directorate of Labour Inspection, Oslo, Norway. The data collection was conducted as part of the Oslo Health Study 2000-2001 in collaboration with the Norwegian Institute of Public Health.

\section{References}

1. Virtanen SV, Notkola V. Socioeconomic inequalities in cardiovascular mortality and the role of work: a register study of Finnish men. Int J Epidemiol. 2002;31:614-21.

2. Marmot MG, Bosma H, Hemingway H, Brunner E, Stansfeld S. Contribution of job control and other risk factors to social variations in coronary heart disease incidence. Lancet. 1997;350:235-9.

3. Rahkonen O, Laaksonen M, Martikainen P, Roos E, Lahelma E. Job control, job demands, or social class?: the impact of working conditions on the relation between social class and health. J Epidemiol Community Health. 2006;60:50-4.

4. Schrijvers CT, van de Mheen HD, Stronks K, Mackenbach JP. Socioeconomic inequalities in health in the working population: the contribution of working conditions. Int J Epidemiol. 1998;27:1011-8.

5. Borg V, Kristensen TS. Social class and self-rated health: can the gradient be explained by differences in life style or work environment? Soc Sci Med. 2000;51:1019-30.
6. Hemström Ö. Health inequalities by wage income in Sweden: the role of work environment. Soc Sci Med. 2005;61:637-47.

7. Molarius A, Berglund K, Eriksson C, Lambe M, Nordström E, Eriksson HG, et al. Socioeconomic conditions, lifestyle factors, and self-rated health among men and women in Sweden. Eur J Public Health. 2007;17:125-33.

8. Laaksonen M, Rahkonen O, Martikainen P, Lahelma E. Associations of psychosocial working conditions with self-rated general health and mental health among municipal employees. Int Arch Occup Environ Health. 2006;79:205-12.

9. Melchior M, Roquelaure Y, Evanoff B, Chastang JF, Ha C, Imbernon $\mathrm{E}$, et al. Why are manual workers at high risk of upper limb disorders?: the role of physical work factors in a random sample of workers in France (the Pays de la Loire study). Occup Environ Med. 2006;63:754-61.

10. Aittomäki A, Lahelma E, Rahkonen O, Leino-Arjas P, Martikainen P. The contribution of musculoskeletal disorders and physical workload to socioeconomic inequalities in health. Eur J Public Health. 2006;17:145-50.

11. Melchior M, Krieger N, Kawachi I, Berkman LF, Niedhammer I, Goldberg M. Work factors and occupational class disparities in sickness absence: findings from the GAZEL cohort study. Am J Public Health. 2005;95:1206-12.

12. Vahtera J, Virtanen P, Kivimäki M, Pentti J. Workplace as an origin of health inequalities. J Epidemiol Community Health. 1999;53:399-407.

13. Hagen KB, Tambs K, Bjerkedal T. What mediates the inverse association between education and occupational disability from back pain?-a prospective cohort study from the Nord-Trøndelag health study in Norway. Soc Sci Med. 2006;63:1267-75.

14. Norwegian Institute of Public Health. The Oslo Health Study [Internet]. Oslo: Norwegian Institute of Public Health [updated June 2008, cited 22 August 2008]. Available from: http://www.fhi.no/eway/default.aspx?pid=233\&trg=MainLeft 5588\&MainArea 5661=5588:0:15,1869:1:0:0:::0:0\&MainLeft_5588=5544:69686::1:5673:1::0:0:

15. Holme I, Helgeland A, Hjermann I, Leren P, Lund-Larsen PG. Four-year mortality by some socioeconomic indicators: the Oslo study. J Epidemiol Community Health. 1980;34:48-52.

16. Rognerud MA, Krüger $\varnothing$, Gjertsen F, Thelle DS. Strong regional links between socio-economic background factors and disability and mortality in Oslo, Norway. Eur J Epidemiol. 1998;14:457-63.

17. Mehlum IS, Kjuus H, Veiersted KB, Wergeland E. Self-reported work-related health problems from the Oslo Health Study. Occup Med (Lond). 2006;56:371-9.

18. National Research Council, Institute of Medicine. Musculoskeletal disorders and the workplace: low-back and upper extremities. Washington (DC): National Academy Press; 2001.

19. Statistics Norway. Survey of living conditions 2000: working environment. Oslo: Statistics Norway; 2001.

20. Erikson RR, Goldthorpe JH, Portocarero L. Intergenerational class mobility in three Western European societies: England, France and Sweden. Br J Sociol. 1979;30:415-41.

21. Erikson R, Goldthorpe JH. The constant flux: a study of class mobility in industrial societies. Oxford (UK): Claredon Press; 1992.

22. Kunst A, Bos V, Mackenbach J, EU Working Group on Socioeconomic Inequalities in Health. Monitoring socio-economic inequalities in health in the European Union: guidelines and illustrations: a report for the Health Monitoring Program of the European Commission. Rotterdam (Netherlands): Department of Public Health, Erasmus University; 2001. 
23. Mackenbach JP, Kunst AE. Measuring the magnitude of socio-economic inequalities in health: an overview of available measures illustrated with two examples from Europe. Soc Sci Med. 1997;44:757-71.

24. Greenland SS. Model-based estimation of relative risks and other epidemiologic measures in studies of common outcomes and in case-control studies. Am J Epidemiol. 2004;160:301-5.

25. Altman DG, Deeks JJ, Sackett DL. Odds ratios should be avoided when events are common. BMJ. 1998;317:1318.

26. Greenland S. Application of stratified analysis methods. In: Rothman KJ, Greenland S, editors. Modern epidemiology. Philadelphia (PA): Lippincott-Raven Publishers; 1998. p 281-300.

27. Eide GE. How to estimate attributable fractions in STATA: a simple introduction. Bergen (Norway): Centre for Clinical Research; 2006. Research report 4.

28. Søgaard AJ, Selmer R, Bjertness E, Thelle D. The Oslo Health Study: the impact of self-selection in a large, population-based survey. Int J Equity Health. 2004;3:3.

29. Galea S, Tracy M. Participation rates in epidemiologic studies. Ann Epidemiol. 2007;17:643-53.

30. Statistics Norway. Labour Force Survey [Internet]. Oslo: Statistics Norway [cited 22 August 2008]. Available from: www. ssb.no/arbeid_en.

31. Martikainen P, Valkonen T. Bias related to the exclusion of the economically inactive in studies on social class differences in mortality. Int J Epidemiol. 1999;28:899-904.

32. Balogh I, Ørbæk P, Ohlsson K, Nordander C, Unge J, Winkel J, et al. Self-assessed and directly measured occupational physical activities-influence of musculoskeletal complaints, age and gender. Appl Ergon. 2004;35:49-56.

33. Östlin P. Negative health selection into physically light occupations. J Epidemiol Community Health. 1988;42:152-6.

34. Brage S, Bjerkedal T, Bruusgaard D. Occupation-specific morbidity of musculoskeletal disease in Norway. Scand J Soc Med. 1997;25:50-7.

35. Stock SR, Fernandes R, Delisle A, Vézina N. Reproducibility and validity of workers' self-reports of physical work demands [review]. Scand J Work Environ Health. 2005;31(6):409-37.

36. Björkstén MG, Boquist B, Talbäck M, Edling C. The validity of reported musculoskeletal problems: a study of questionnaire answers in relation to diagnosed disorders and perception of pain. Appl Ergon. 1999;30:325-30.

37. Kristensen P. Bias from nondifferential but dependent misclassification of exposure and outcome. Epidemiology. 1992;3:210-5.

38. Podsakoff PM, MacKenzie SB, Lee JY, Podsakoff NP. Common method biases in behavioral research: a critical review of the literature and recommended remedies. J Appl Psychol. 2003;88:879-903.

39. Toomingas A, Alfredsson L, Kilbom A. Possible bias from rating behavior when subjects rate both exposure and outcome. Scand J Work Environ Health. 1997;23(5):370-7.

40. Kunst AE, Bos V, Lahelma E, Bartley M, Lissau I, Regidor E, et al. Trends in socioeconomic inequalities in self-assessed health in 10 European countries. Int J Epidemiol. 2005;34:295-305.

41. Krokstad S, Kunst AE, Westin S. Trends in health inequalities by educational level in a Norwegian total population study. J Epidemiol Community Health. 2002;56:375-80.

42. Rognerud MA, Zahl PH. Social inequalities in mortality: changes in the relative importance of income, education and household size over a 27-year period. Eur J Public Health. 2006;6:62-8.

43. Brekke M, Hjortdahl P. Musculo-skeletal pain among 40- and 45-year olds in Oslo: differences between two socioeconomi- cally contrasting areas, and their possible explanations. Int $\mathrm{J}$ Equity Health. 2004;3:10.

44. Kristensen P, Bjerkedal T, Irgens LM. Early life determinants of musculoskeletal sickness absence in a cohort of Norwegians born in 1967-1976. Soc Sci Med. 2007;64:646-55.

45. Brekke M, Hjortdahl P, Kvien TK. Severity of musculoskeletal pain: relations to socioeconomic inequality. Soc Sci Med. 2002;54:221-8.

46. Dionne CE, Von KM, Koepsell TD, Deyo RA, Barlow WE, Checkoway H. Formal education and back pain: a review. J Epidemiol Community Health. 2001;55:455-68.

47. Dahl E, Fritzell J, Lahelma E, Martikainen P, Kunst A, Mackenbach JP. Welfare state regimes and health inequalities. In: Siegrist J, Marmot M, editors. Social inequalities in health. Oxford (UK): Oxford University Press; 2006. p 193-222.

48. Lundberg $\mathrm{O}$. Ojämlikhet i hälsa: definitioner, mått, mekanismer och policyimplikationer [Inequalities in health: definitions, measures, mechanisms, and policy implications]. Socialmed tidsskr. 2003;3:200-8.

49. Palmer KT, Smedley J. Work relatedness of chronic neck pain with physical findings - a systematic review. Scand J Work Environ Health. 2007;33(3):165-91.

50. Bongers PM, IJmker S, van den Heuvel S, Blatter BM. Epidemiology of work related neck and upper limb problems: psychosocial and personal risk factors (part I) and effective interventions from a bio behavioural perspective (part II). J Occup Rehabil. 2006;16:272-95.

51. Hoogendoorn WE, van Poppel MN, Bongers PM, Koes BW, Bouter LM. Systematic review of psychosocial factors at work and private life as risk factors for back pain. Spine. 2000;25:2114-25.

52. Warren JR, Hoonakker P, Carayon P, Brand J. Job characteristics as mediators in SES-health relationships. Soc Sci Med. 2004;59:1367-78.

53. Hagen KB, Holte HH, Tambs K, Bjerkedal T. Socioeconomic factors and disability retirement from back pain: a 19831993 population-based prospective study in Norway. Spine. 2000;25:2480-7.

54. Drever F, Doran T, Whitehead M. Exploring the relation between class, gender, and self rated general health using the new socioeconomic classification: a study using data from the 2001 census. J Epidemiol Community Health. 2004;58:590-6.

55. Mackenbach JP, Kunst AE, Cavelaars AE, Groenhof F, Geurts $\mathrm{JJ}$, the EU Working Group on Socioeconomic Inequalities in Health. Socioeconomic inequalities in morbidity and mortality in western Europe. Lancet. 1997;349:1655-9.

56. Galobardes B, Lynch J, Davey Smith G. Measuring socioeconomic position in health research. Br Med Bull. 2007;81-82:21-37.

57. Arber S. Gender and class inequalities in health: understanding the differentials. In: Fox J, editor. Health inequalities in European countries. Aldershot (UK): Gower; 1989. p. 50-279.

58. Krantz G, Berntsson L, Lundberg U. Total workload, work stress and perceived symptoms in Swedish male and female white-collar employees. Eur J Public Health. 2005;15:209-14.

59. Galobardes B, Shaw M, Lawlor DA, Lynch JW, Davey Smith G. Indicators of socioeconomic position (part 1). J Epidemiol Community Health. 2006;60:7-12.

60. Galobardes B, Shaw M, Lawlor DA, Lynch JW, Davey Smith G. Indicators of socioeconomic position (part 2). J Epidemiol Community Health. 2006;60:95-101.

61. Lundberg O. Causal explanations for class inequality in healthan empirical analysis. Soc Sci Med. 1991;32:385-93.

Received for publication: 30 June 2008 